This is the peer reviewed version of the following article: Ranta, Ronald (2019) Dissonance on the Brexit menu : what does Britain want to eat? The Political Quarterly, 90(4), pp. 654-663., which has been published in final form at https://doi.org/10.1111/1467-923X.12776. This article may be used for noncommercial purposes in accordance with Wiley Terms and Conditions for Use of Self-Archived Versions. 


\section{Dissonance on the Brexit menu: What does Britain want to eat?}

\section{Ronald Ranta, Department of Politics, Kingston University, London}

This article focuses on the future of food in the UK in the context of Brexit. It examines the claims and promises made by Brexiteers before the referendum and juxtaposes these with the approach pursued by the Conservative-led government since. The article argues that there is a clear dissonance between the two. This dissonance is the result of two important factors. First, the government is stuck in a non-decision making mode, making it unable to pursue clear policies. Second, the food claims and promises made by Brexiteers are in opposition to what the vast majority of the public, food experts, farmers and food businesses want. Through exploring these two factors, and the Brexiteers claims and promises, the article explains what leaving the EU might mean for the future of food in the UK.

Key words: Brexit, European Union, non-decisions, farming, food policy, food regulation

\section{What about food?}

Unlike immigration and sovereignty, food did not feature heavily in the run up to Britain's European Union (EU) membership referendum in 2016. Food did come up briefly in postreferendum negotiations between the UK and the EU, particularly with regard to Northern Ireland. However, it only became an issue of public concern when reports of a potential USUK free trade agreement (FTA) appeared in the media, mostly in relation to controversial US farm practices, and with regard to the short-term implications of a no deal Brexit. The lack of discussion regarding food occurred despite the fact that the long-term 'implications of Brexit for food are potentially enormous' and this applies regardless of which form of Brexit is adopted. ${ }^{1}$ From the price, choice and standards of the food available to the health and sustainability of UK farming and food supply chains, Brexit has the potential for dramatically altering the way food is governed and dealt with, but also what people will shop and eat.

Despite the fact that food was barely discussed in the run up to the referendum, leading proponents of leaving the EU (Brexiteers) did advance a number of food related arguments; Vote Leave (the official leave campaign) had a section on its website dedicated to farming, 
fisheries and food. Brexiteers highlighted a number of areas in which they claimed EU membership hurt British consumers, food businesses and farmers. They also put forward policy recommendations and ideas regarding the future of agriculture and food post-Brexit. One of the main arguments advanced was that it would be advantageous for the UK to leave EU regulatory bodies and frameworks. In terms of food, they argued that such a move would include the possibility of setting British own food standards, improving agricultural productivity, reducing unnecessary red tape, bringing down food prices, and pursuing FTAs with major food producers, such as the US and Australia.

The claims made by Brexiteers present a particular vision of the future of food in the UK postBrexit. When this vision is juxtaposed with the approaches pursued by the Conservative led government, its negotiating team with the EU and the Department for environment, food and rural affairs (DEFRA), an apparent contradiction appears. There is a clear dissonance between the pre-referendum promises and the post-referendum reality. By trying to clarify why this is the case, this article highlights and clarifies the benefits, trade-offs and costs associated with Brexit and explains what leaving the EU might mean for the future of food in the UK.

\section{Brexit menu}

According to the Guardian newspaper, during the 2019 Conservative party leadership contest, Boris Johnson claimed that the EU imposed 'pointless, pointless, expensive, environmentally damaging health and safety' regulations and requirements on UK food businesses. Johnson gave the example of the costs incurred by a kipper (smoked whole herring) producer from the Isle of Man who had to add a small 'plastic ice pillow' to each kipper sent by post. There was one small problem with Johnson's example, the specific requirement to keep food cold while in transport from the producer to the costumer did not come from the EU. It is based on the advice of the UK's Food Standard Agency (FSA), which states on its website that 'foods that need refrigerating must be kept cool while they are being transported'. The FSA, however, does not specifically require the need for plastic ice pillows.

The claim that EU food regulations are mostly pointless and place undue burden on UK food businesses is one that has been repeatedly made by leading Brexiteers. The opposition to, and at times ridicule of EU regulations has also been a feature of the British tabloid press for decades. In many ways, the story of the kipper's 'plastic ice pillows' is part of a long list of 
misleading and inaccurate food related claims made by the tabloid press. These claims include the assertions that under EU regulations cod will no longer be labeled as cod; Bombay mix will be renamed Mumbai mix; the Union Jack flag will be banned from British meat exports; Caerphilly cheese production in Caerphilly will end; and brandy butter will be renamed brandy spreadable fat. ${ }^{2}$ Stories such as these have helped shape British public opinion towards the EU, which has created a dissonance between the work done by the EU on issues concerning food security, safety and standards, and the general public's perception of the EU.

In the run up to the referendum, the leave campaign argued that EU rules and regulations were hampering and restricting British farming and food businesses. Several rules and regulations were particularly highlighted. These included rules on the use of pesticides; the ban on genetically modified (GM) food and feed; and rules on labelling. On its website, Vote Leave argued that rules on pesticides deny 'business access to innovative crop protection products. This hinders EU businesses in their efforts to improve crop yields and quality'. The rules on GM food were claimed to hinder British farmers' competitiveness in the global market. It was argued that rules on labeling 'imposed silly requirements' on and added unnecessary costs to UK businesses. In short, Vote Leave claimed that EU rules and regulations did little for consumer safety and animal welfare, harmed jobs, 'cost farmers millions, destroy businesses, and harm the environment'.

It was not simply EU rules and regulations that Vote leave and leading Brexiteers were unhappy with. They were unhappy with the EU's overall approach to food and in particular its Common Agricultural Policy (CAP). CAP, which consumes over a third of the EU's budget, is meant to support European farmers and rural communities, through a system of direct payments and subsidies, and help secure food prices and supplies, among other things. Brexiteers claimed that CAP was bad for UK farmers, expensive, wasteful and bureaucratic, and imposed punitive tariffs against third world countries. George Eustice, who at the time of the referendum was the Minister of State for agriculture, fisheries and food, and who campaigned for Brexit, argued that it would be better for UK farmers to be out of CAP as it was stifling and wasteful, and that they would be better off receiving subsidies from the UK government. Another leading Brexiteer, the Conservative MP Owen Paterson, who had previously served as the Secretary of State for environment, food and rural affairs, argued that only by leaving the EU and CAP would the UK be able to increase farm output and work with like-minded countries to combat plant and animal diseases. According to Vote Leave, leaving the EU would allow the UK to decide its own rural and agricultural policies; pursue FTAs, which they claimed would benefit 
British farmers and consumers; increase food production and farm productivity; and lower food prices.

The subject of food prices is interesting to examine because it is the most tangible one, as it directly affects consumers, and was one of the few food-related issues broached by both sides of the referendum campaign. During the referendum, Vote Leave claimed that Brexit would lead to cheaper food prices. The basis for the claim was that lower food prices would be achieved through a two-pronged approach. First, it was claimed that greater competitiveness in the food sector coupled with increased farm productivity, through economies of scale and a reduction in unnecessary and costly rules and regulations would bring down domestic prices. Second, it was claimed that imported food prices would also be brought down through new FTAs with leading food producing countries, which would be accompanied by lower tariffs and non-tariff barriers. Daniel Hannan, a Conservative member of the European Parliament (MEP), and a prominent Brexiteer and free trade advocate, argued that much of the EU's food standards and regulations were barriers to trade that had little 'genuine public health justification'. Removing these would therefore bring down food prices and pose no risk. It was also claimed that future FTAs would include many developing countries, which would benefit directly; this was put against the charge that EU trade policies and practices were particularly unfair towards developing countries.

Stronger IN, the official remain campaign, as well as the National Farmers Union (NFU), argued that only continued membership of the EU would provide the UK with access to cheap food. Stronger In argued that 'Being in the EU means you pay less for your weekly food shop', while the NFU warned that leaving would make 'it more expensive to feed your family'. The reason put forward was that leaving the EU would entail higher tariffs and trade barriers between the UK and the EU, from which the UK imports around 30 per cent of its food. Leaving would also make farmers dependent on exports to the EU worse off, as 60 per cent of UK food exports go to the EU. ${ }^{3}$ It was also argued that leaving the EU would precipitate a drop in the value of the pound, which would reduce the amount of money families had to spend.

Interestingly, the debate over food prices is similar to the one the UK had during the 1975 referendum on its membership of the European Community (EC), the precursor to the EU. The debate then, as is today, concerned the fact that the UK was not self-sufficient in food and required imports for its food security. In their official leaflets, the In campaign in 1975 - in favor of staying in the EC - argued that 'Britain, as a country which cannot feed itself, will be 
safer in the Community which is almost self-sufficient in food', and that only membership of the EC would guarantee food security and 'secure food at fair prices'. The OUT campaign argued that food prices would 'rise higher and higher' because of inefficient EC food regulations and bureaucracy and the UK's inability to pursue its own food policies, including pursuing FTAs with other food producing countries.

There are a number of points that arise from this debate. First, since the 1975 referendum, UK food imports now account for half the food eaten in the country, much of which comes from the EU, but UK households spend only 8 per cent of their budget on food (this excludes eating out), a percentage that is one of the lowest in the world. ${ }^{4}$ A second point to consider is that lowering food prices might undercut UK farmers and force structural changes on UK farming. Lastly, lower food prices might not necessarily be in the interest of UK farmers or the general public, particularly 'if they are at odds with either environmental sustainability or positive health outcomes' 5

\section{A green Brexit?!}

During the referendum, Brexiteers put forward their vision for the future of food in the UK post-Brexit. The UK would become, to paraphrase Boris Johnson, a new Singapore on the Thames, a global free-trading economy with low food tariffs and few non-tariff barriers, low regulations, and increased consumer choice. UK domestic food sector would benefit from the removal of wasteful and inefficient EU subsidies; and changes to the rules and regulations that govern the use of food labeling, GM and pesticides, among many others things, will encourage greater competition and higher productivity. What is striking, however, in the aftermath of the referendum, is how far removed the Conservative government's rhetoric, negotiated position and actual proposals, under Theresa May (July 2016- July 2019), have been from this vision.

In its negotiations with the EU, the May government pursued a somewhat contradictory approach. On the one hand, it aimed to keep the UK in regulatory alignment with EU, which would have meant closely following EU food standards, rule and regulations. On the other hand, it tried to ensure its ability to pursue FTAs with leading food producing countries. This approach crystallised on the $6^{\text {th }}$ of July 2018 with the Chequers Plan. While the plan did not specifically address food it aimed at establishing a common rule book for agricultural products and maintaining overall high regulatory standards. The Chequers Plan, and its perceived 
deviation from pre-referendum promises, prompted the resignation of several Brexit supporting ministers, among them the Foreign Secretary Boris Johnson and the Brexit Secretary David Davis. Chequers in the eyes of the Brexiteers would make a mockery of Brexit and, by pursuing regulatory alignment, deny Britain the opportunity to break away from EU rules and regulations and negotiate new FTAs.

Despite criticism from the Brexit supporting press and Conservative back benchers, the government solidified its position, and its departure from the pre-referendum Brexit vision, with its support for the Withdrawal Agreement (WA), which was approved by the cabinet on the $14^{\text {th }}$ of November 2018 . The WA confirmed that the UK would remain in close regulatory alignment with the EU in order to ensure that there would be no hard border between Northern Ireland and Ireland. Additionally, the government agreed that until additional measures were found to ensure an open border, Northern Ireland would remain in the Customs Union and large parts of the Single Market, implying that many EU food regulations and rules would persist. May's insistence that Northern Ireland would not be treated differently from the rest of the country meant that the same rules and regulations would apply to the UK as a whole even after Brexit.

Another important aspect of the WA was the agreement by both sides to recognise and legally protect the existing stock of EU-approved geographical indications (GIs), which include protected designation of origin, protected geographical indications, and traditional specialities, until a final Brexit agreement was concluded. The EU's GI framework treats food that is produced in a particular region, or has been produced in a particular way, as intellectual property. There are more than 3000 GIs in place at the moment, which include, among others, a wide range of wines, pastries, cheeses, and cured meat. The agreement would have covered and benefited the several dozen GIs of UK origins, such as Welsh lamb, Melton Mowbray pork pie, Cornish clotted cream, Jersey Royal potatoes, Arbroath smokies, Cornish pasty, and Scotch whisky. Besides playing an important role for local and regional food producers and communities, GIs also have an important role in FTAs; the EU includes the protection of its GIs in its FTAs. Any decision by the UK to legally recognise EU GIs might, to an extent, complicate future FTAs as well as limit the range of products that could be included.

The WA also included a transitional period up until December 2020. During the transitional period all relevant EU rules and regulations and the supremacy of EU regulatory bodies were expected to continue. The UK was expected during this period to design, and afterwards apply 
a new legislative framework for food regulations and to setup new UK only regulatory bodies. The WA precipitated another round of resignations among Brexit supporting ministers, among them the Brexit Secretary Dominic Raab, who had replaced Davis in July.

The WA and the Chequers Plan demonstrated a deviation from the pre-referendum promises. However, nowhere was this deviation as stark as the pursuit, by Michael Gove the Secretary of State for environment, food and rural affairs (DEFRA) and leading Brexiteer, of a 'Green Brexit'. The pursuit of a Green Brexit put to question the whole premise of lowering food standards, and eliminating rules and regulations regarding GM products and pesticides among other things. It also put to question the entire Brexiteer rationale of leaving the EU and taking back control.

In February 2018, DEFRA published its post-Brexit consultation paper titled 'Health and harmony: the future for food, farming and the environment in a green brexit'. In the foreword to the paper Gove argued that during the UK's membership of the EU, and while inside CAP, its 'environment has deteriorated, productivity has been held back and public health has been compromised'. Brexit, according to Gove, presented the UK with an opportunity not to lower food and agricultural standards but to raise them. The term high standards appears dozens of times in the paper, in relation to animal health and welfare, the environment and consumers. In its Green Brexit paper, DEFRA envisioned farmers as stewards of the environment that would be rewarded through a new subsidy system. The new subsidy system, which would replace the CAP one, would see a reduction in subsidies, particularly for larger farms, and future payments linked to environmental land management. Through this new system farmers would be required to provide better animal welfare and plant health standards; enhance and protect the environment; increase biodiversity; and mitigate climate change impacts; while improving productivity and competitiveness. On the issue of pesticides, the paper states the importance of strong regulations, to limit the risks, and 'using all available tools to protect crops, with the least possible use of pesticides'. The document does not directly address the issue of GM crops other than to list gene editing as one of a range of innovations that would lead to higher farm productivity.

While not specifically affirming his approval of the Green Brexit initiative, since taking office on $24^{\text {th }}$ July 2019, Conservative Prime Minister Boris Johnson has stated his support for the work done by DEFRA and Gove; he has also reappointed George Eustice, a strong advocate of a Green Brexit, as the Minister of State for agriculture, fisheries and food. Johnson has also 
stated in an open letter to the NFU that he would not undermine Britain's 'own high domestic production standards', and according to the Farmers Guardian newspaper has claimed he would look to 'boost standards' and 'enhance consumer safety'.

\section{No appetite for Non-decision making}

The idea of pursuing a Green Brexit - of maintaining or improving food and animal welfare standards and providing better environmental stewardship - coupled with the WA, which keeps the UK in close regulatory alignment with the EU, is surprising given the statements made by Brexiteers regarding agricultural productivity, food prices, and FTAs. It raises two important questions regarding food and Brexit. First, if the UK wishes to maintain high food and animal welfare standards and remain in close regulatory alignment with the EU, which would make it harder for it to sign FTAs, why does it want to leave the EU? The Green Brexit approach would make it harder to dramatically increase productivity or lower food prices. Second, it raises the question of why the May government's approach differed from the pre-referendum vision put forward by Brexiteers.

Before answering these questions it is important to add a crucial caveat to the above discussion on a Green Brexit. While the consultation paper presented a particular approach towards the future of farming and agriculture in the UK, the implementation of much of the recommendations will depend on, yet to be created, new regulatory bodies and frameworks. With the current level of uncertainty, the chances of a no deal Brexit, and lack of drive towards setting up new regulatory bodies, the Green Brexit paper could end up as nothing more than an aspirational wish list rather than actual policy; the lack of substance and detail in DEFRA's follow on Agricultural Bill 2017-2019 gives credence to this view.

In addressing the reasons why the May government appeared to have pursued a different approach to food and agriculture after Brexit there are two important issues to consider. First, neither the government's approach nor the various statements made by leading Brexiteers pre and post the referendum amount to a clear and comprehensive strategy of addressing the future of food in the UK, and this includes the new Johnson government as will be discussed below.

The current vision of a Green Brexit appears to be a continuation of the approach taken by the coalition government (Liberal Democrat-Conservative Coalition 2010-2015). The Coalition Government's stated policy document regarding food and farming (2012-2015) supported 'a 
strong and sustainable green economy', the need to 'enhance the environment and biodiversity' and 'encourage sustainable food production'. The suggestions put forward included many issues, such as food waste, food supply chains, skill shortages and diet and consumption, not addressed by either the May or Johnson governments. After the 2015 elections, the elected Conservative government launched a round of consultations on a proposed new 25 year plan on the future of food and farming. One would imagine that this would have loosely followed the Coalition Government's policy, while encouraging further liberalisation. Brexit, however, changed all of that. The government did not expect to lose the referendum and therefore did not set out in any detail its post-Brexit food policies.

According to Farmers Weekly, in response to questions, during the 2016 Oxford Farming Conference, and before the referendum, the then DEFRA Secretary Liz Truss referred to Brexit as a 'leap in the dark', and claimed the government was 'not working on an alternative plan for the country's farm sector in case the UK votes to leave the EU'. George Eustice, the then Minister of State for Agriculture, Fisheries and Food, later qualified that statement by arguing that some policies were being outlined, specifically around subsidies. Nevertheless, the general impression given was that there was no clear post-Brexit policy on the future of food, or for that matter with regard to anything.

In terms of Vote Leave and the leading Brexiteers, while they had a number of neoliberal slogans, they never presented a clear vision for food in the UK post-Brexit. There was a lot of rhetoric about the benefits of lowering food prices and tariffs, increasing trade and cutting red tape, but rarely did they discuss the costs and tradeoffs of these suggestions. They also rarely addressed the main food-related issues the UK was actually facing. There was no discussion on issues such as food waste, increasing use of food banks, or the worrying levels of malnutrition, hunger and obesity in the UK. For example, the rise in use of food banks is not an issue that could be resolved simply through lower food prices, but is the result of poverty, changes to the benefits system, and the impact of years of austerity. ${ }^{6}$ Additionally, there has been little information on how food insecurity in the UK would be addressed post-Brexit. In its July 2018 report, the UK Stakeholders for Sustainable Development stated that the government 'is failing to address malnutrition in all forms, with food insecurity and obesity rising' and that levels of adult and child food insecurity were among the worst, 'if not the worst', in Europe. ${ }^{7}$ 
The lack of clear policy was not only a feature of the pre-referendum leave campaign, the 2017 elected Conservative minority government did not bring forward a clear and coherent longterm vision with regard to food in the UK post-Brexit. The overall uncertainty regarding Brexit, and being a minority government, made it hard to put forward let alone implement coherent policies on any issue. In many ways the government was and still is caught in a classic case of non-decision making.

The concept of non-decision refers to 'the practice of limiting the scope of actual decision making to safe issues' resulting 'in suppression or thwarting of a latent challenge to the values or interests of the decision maker'. ${ }^{8}$ Non-decisions are normally associated with coalition governments and paralysis of the decision-making process. Decision making in these circumstances becomes ad-hoc and short-termism with policy makers pursuing often diverging agendas. ${ }^{9}$ This appears to be the case with the May government's attempt to satisfy ministers dreaming of a 'Singapore on the Thames' and those pursuing a 'Green Brexit', while, at the same time, negotiating with and being pressured by the EU. In short, the government cannot afford to decide, because any decision has the potential of derailing Brexit and reducing the government's scope for manoeuvre.

The lack of a clear policy is also apparent with regard to the newly established Johnson government, which appears intent on saying all things to all people. While speaking of boosting productivity, enhancing efficiency, and pursuing free trade agreements with leading food exporting countries, in particular with the US, Johnson has also claimed to support sustainable growth, high domestic standards and increased consumer safety. With regard to a no deal Brexit, while Johnson has promised to support farmers and food businesses, he has provided little substance on what the implications his approach would have on food in the UK.

The second main reason why May's government rhetoric and approach appears to differ from the pre-referendum vision is that it is not supported by a majority of the public, leading food experts, farmers, food businesses and MPs. In the run up to the referendum, Brexiteers promised the public a return to the glory days of the Empire with Britain signing numerous FTAs and reemerging as a global trading hub. However, the public were told little of what these agreements would consist of and how they would affect their lives, particularly in terms of how they might affect food and farming in the UK. The countries highlighted as immediate targets for FTAs included the US, Australia, New Zealand, and Canada, all of which are agricultural powerhouses. The latter three are members of the Cairns group of agricultural 
exporting countries, who have long sought more access to European markets; Canada has recently concluded a FTA with the EU, while New Zealand and Australia are in the process of negotiating ones. More access is mostly associated with lowering tariffs. However, in the case of the above countries, while tariffs over food could be lowered, the scope for more access mostly revolves around food regulation, labelling and recognition of standards.

The government's desire to conclude FTAs and make a success of Brexit has the potential of testing the public and the food sector's appetite for changes to current food regulations and standards (i.e. non-tariff barriers). FTAs with the above mentioned countries raise concerns for many UK dairy and livestock farmers, regarding potential impacts to their livelihood and business models from cheaper imports and reduced access to the EU; for example, lamb farmers might face competition from cheaper New Zealand lamb imports, while facing increased trading barriers and tariffs of around 40 per cent with the EU, which currently buys 90 per cent of lamb exports. The difficulties of addressing cheaper imports and increased trading barriers with the EU would be further exacerbated in the case of a no deal Brexit. The National Sheep Association has written an open letter to Prime Minister Johnson stating that leaving without a deal would 'cripple' their trade and asking for substantial government financial and logistical support and the temporary closure of the UK market for sheep meat imports.

The first time issues concerning future FTAs became public was with media reports on what a potential UK-US FTA would look like. According to its supporters, a future FTA would provide US food exporters with a new market and the British public with increased choice and cheaper alternatives. The agreement would save the UK from the EU's unsustainable 'museum of agriculture', according to the US Ambassador to the UK, by requiring it to move away from, what are perceived to be, antiquated, unnecessary and costly EU regulations. ${ }^{10}$ To its detractors, a UK-US FTA has the potential of introducing controversial food practices and products that would harm UK consumers. The particular practices and products that have been highlighted, and which are either banned or used in a limited capacity in the EU, include the use of chlorine wash as a 'pathogen reduction treatment', particularly but not exclusively in poultry; the use of growth hormones and antibiotics in livestock, particularly with regard to cattle; the use of food additives; and the use of GM crops. It is important to note that these practices and products are not limited to the US. The use of chlorine wash for poultry is prevalent in New Zealand; much of Australian beef is hormone treated; and GM crops are grown commercially in Australia and Canada. 
With the exception of a handful of committed Brexiteers, such as MEP Daniel Hannan, who claimed opposition to chlorinated chicken was concentrated among anti-capitalists who don't eat meat, and the Sun newspaper, which argued that the whole story was 'baseless panic', there has been a wholesale rejection of the above mentioned products and practices by the general public, the media, food businesses and farmers, MPs, and even government ministers. Although results vary, a number of surveys conducted by different polling companies indicate clear opposition to the introduction of farming products and practices that are currently banned in the UK. For example, a rolling survey of consumer attitudes towards food, by the consumer group Which?, found that an overwhelming majority (93 per cent) thought it was important to maintain current food standards after Brexit; and were opposed to the introduction of hormone treated beef ( 80 per cent), chlorinated chicken ( 72 per cent) and greater use of GM ingredients (64 per cent). ${ }^{11}$ It is evident from these surveys that there is little demand for the introduction of such practices and products in the UK.

Opposition has also been expressed by a wide range of food and farming bodies. The British Poultry Council has stated that they 'strongly reject any move to import chlorine-washed chickens'. The NUF has argued that future FTAs should 'not serve to allow cheap food imports which undermine the high standards that British farmers are proud to produce food to'. The UK Food and Drinks Industry's Plan for Success, written in June 2019, and representing thirty food and drink organisations across the supply chain, has called on the government to maintain 'a stable and consistent regulatory framework between the UK and EU' and to commit that 'UK food and drink standards will not be sacrificed to secure market access for other industries'. In August 2019, the Country Land and Business Association (CLA) and the Tenant Farmers Association (TFA), which represent a range of rural and agricultural businesses, have called on the government to maintain current standards and to 'ban the importation of any ingredients, intermediate foodstuffs and final foodstuffs produced using techniques banned in the UK for the purpose of protecting the environment, animal welfare or for social concerns'. Concerns over the lowering of food standards and the introduction of currently banned practices and products have also been expressed by leading food experts. ${ }^{12}$

Opposition to lower food standards was also expressed by the House of Lords' EU Committee on Brexit in its 2017 report on farm animal welfare, which stated that 'the greatest threat to farm animal welfare standards post-Brexit would come from UK farmers competing against cheap, imported food from countries that produce to lower standards than the UK'. Interestingly, several Brexit supporting ministers have indicated their opposition, the 
most prominent being Michael Gove, who has stated on numerous occasions that the UK would not accept any lowering of its food standards and would not accept chlorinated chicken. It is not a surprise then that opposition to the lowering of standards became the unofficial government position, though it has not specified, for diplomatic and political reasons, whether it would accept currently banned practices and products as part of future FTAs.

\section{What does Britain want to eat?}

It is clear that so far the government has not attempted to deliver on the Brexiteers' food promises. It has not sought to lower food standards or introduce practices that are currently banned. Instead, it has pursued close regulatory alignment with the EU, at least in the short term, and promised to maintain and even improve food standards. The question of whether it will continue down this path when the UK leaves the EU is still to be seen.

One of the main problems identified in this article is the lack of a clear overall policy towards food post-Brexit. The government has indeed moved away from the Brexiteers' promises, but despite proposing a Green Brexit, no ironclad guarantees have been given, no new regulatory bodies have been set up, and no overall policy or legislation have been put forward, other than on the issue of farming subsidies. Additionally, there has been little effort to address the main food and farming issues the country is facing, many of which would be affected by Brexit.

As has been shown above, there are several reasons why the government has so far not delivered on the Brexit promises. The first and most straight forward is that there has not been and is no clear Brexit food policy. The government is stuck in a classic non-decision mode, with its decision making process in paralysis. As a result of its non-decision, individual policy makers have pursued their own agendas, while paying lip service to the government. On the one hand, Gove has pushed for a Green Brexit and raising food standards. On the other hand, several ministers, including the Secretary of State for International Trade Liam Fox and Boris Johnson have made positive sounds about the potential of a UK-US FTAs and the possibility of accepting US produce currently banned in the EU. The second reason for the government's deviation has been the wide range opposition to the 'Singapore on the Thames' post-Brexit food vision. There appears to be little appetite among the general public, food experts, farmers and producers, food charities, and trade bodies, for the introduction of cheap food imports, banned food practices and products, and lowering of UK food standards. 
Where does all this leave the UK? Starting from the position that the UK will leave the EU and with the current levels of uncertainty this is not a given - one could imagine four possible post-Brexit scenarios. First, the government might reject the lowering of UK food standards and decide to pursue a Green Brexit alongside close regulatory alignment with the EU. While this does not sound on the surface as plausible, particularly given the stance taken by Boris Johnson, it might be imposed on the UK as the only way of securing British food exports to the EU and ensuring an open border in Northern Ireland. While this scenario would provide some scope for the UK to set out its own independent food and trade policy, it would leave many questioning the logic of leaving the EU in the first place.

Second, there is little reason to expect that the current levels of indecision and policy making paralysis would change in the near term future, regardless of the type of Brexit (soft, hard, or no deal). The UK would struggle to come up with coherent solutions to the food challenges it faces and would end up with a series of ad-hoc policies that would leave it with a muddled approach to food post-Brexit.

Third, the desire of Brexiteers for wholesale reform to the food sector, by increasing productivity, reducing rules and regulations, and bringing down prices, and the pressures from food experts, farmers and food bodies, to retain current standards and reject cheap imports, might cause the government to appeal to both by adopting, either by design or by default, a two-tier food system. This would see the 'UK produce food at higher standards but import cheaper and potentially lower-quality food from countries with reduced welfare or environmental standards'. ${ }^{13}$ This approach might satisfy many Brexiteers, but would bring about dramatic structural changes to the UK food sector, while potentially alienating consumers, and farmers, who would prefer to maintain a level playing field.

Fourth, Prime Minister Johnson might decide to make good on the pre-referendum promises and his own past statements. He would pursue FTAs with leading food producing countries, a looser FTA with the EU, and deregulate and liberalise the UK food sector. This would see the introduction of currently banned practices and products and cheaper imports, in the name of consumer choice and increased competition and productivity. While a debate could be had on the long-term impacts of such an approach, the short-term impact would be dramatic and would see whole scale structural changes to the UK's food and farming sector. It might well achieve higher productivity and lower food prices, but the costs could be a race to the bottom in terms 
of food safety and standards, which might alienate consumers and farmers, and could adversely affect public health.

One thing is clear, whichever approach is adopted post-Brexit, leaving the EU will have an immediate, direct and long-lasting impact on consumers and on food in the UK. It is therefore imperative that there is a meaningful engagement with the public on what it wants to eat postBrexit.

\footnotetext{
${ }^{1}$ Lang, Tim. Millstone, Erik and Terry Marsden (2017) A Food Brexit: time to get real. A Brexit briefing.

${ }^{2}$ Available at: https://blogs.ec.europa.eu/ECintheUK/euromyths-a-z-index/ (accessed 8.5.2019).

${ }^{3}$ Department for Environment, Food \& Rural Affairs (2018) Agriculture in the United Kingdom 2017.

${ }^{4}$ Office of National Statistics (2018) Family Spending in the UK: April 2017 to March 2018. Available at: https://www.ons.gov.uk/peoplepopulationandcommunity/personalandhouseholdfinances/expenditure/bulleti ns/familyspendingintheuk/financialyearending2018 (accessed 8.5.2019).

${ }^{5}$ Benton, G. Tim et al. (2019) Food Politics and Policies in Post-Brexit Britain. A Chatham House Research paper. ${ }^{6}$ Loopstra, $\mathrm{R}$ et al. (2015) Austerity, sanctions, and the rise of food banks in the UK, BMJ, DOI: http://doi.org/10.1136/bmj.h1775

${ }^{7}$ UKSSD (2018) Measuring up: How the UK is performing on the UN Sustainable Development Goals. Available at: https://www.ukssd.co.uk/measuringup (accessed 15.5.2019).

${ }^{8}$ Bacharach, Peter and Morton Baratz (1963) 'Decisions and Nondecisions: An Analytical Framework' The American Political Science Review 57(3) pp. 632-642.

${ }^{9}$ Ranta, Ronald (2015) The Decision not to Decide: Israel and the Occupied Territories 1967-1977 (Basingstoke, Palgrave Macmillan).

${ }^{10}$ Transcript of US Ambassador Woody Johnson's comments, available at: https://uk.usembassy.gov/dont-letsmears-about-u-s-farms-trap-britain-into-the-eus-museum-of-agriculture/ (accessed 12.5.2019).

${ }^{11}$ Available at: https://production-whichdashboard.s3.amazonaws.com/system/articles/attachments/1/Brexit and Food April 2018 FINAL.pdf (accessed 12.5.2019).

${ }^{12}$ See, for example, Lang, Tim. Millstone, Erik and Terry Marsden (2017) Will the British public accept chlorinewashed turkey for Christmas dinner, after Brexit? FRC Food Brexit Policy Briefing.

${ }^{13}$ Benton, G. Tim et al. (2019) Food Politics and Policies in Post-Brexit Britain. A Chatham House Research paper.
} 